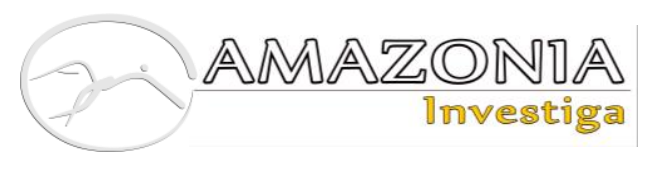

DOI: https://doi.org/10.34069/AI/2021.44.08.1

How to Cite:

Budnyk, O., Mazur, P., Matsuk, L., Berezovska, L., \& Vovk, O. (2021). Development of professional creativity of future teachers (Based on comparative research in Ukraine and Poland). Amazonia Investiga, 10(44), 9-17. https://doi.org/10.34069/AI/2021.44.08.1

\title{
Development of professional creativity of future teachers (Based on comparative research in Ukraine and Poland)
}

\author{
Розвиток професійної креативності майбутніх учителів \\ (за результатами порівняльних досліджень в Украӥні та Польщі)
}

Received: July 10, 2021

Abstract

The article outlines the essence of professional creativity in pedagogical activity. The teacher's creativity is described as a complex of intellectual and personality characteristics of the individual, contributing to the independent generation of original ideas and their nontraditional solution. On the basis of comparative experimental research, the level of non-verbal creativity of future teachers of the bordering regions of Ukraine and Poland was revealed in the paper. According to the results of the diagnosis of non-verbal creativity (Torrens methods), the authors conclude that a significant proportion of Ukrainian and Polish students are not able to produce a sufficient number of original ideas in a minimal verbalization (for example, most of the future teachers had the average $(47.3 \%$ in Ukraine, $45.8 \%$ in Poland) and low (respectively $18.7 \%$ and $25.8 \%$ ) levels of non-verbal creativity based on the index of originality). It is emphasized on the need to focus the content of higher education on the development of future teachers' ability to seek out non-standard options in organizing the
Accepted: August 15, 2021

Written by:

Olena Budnyk

https://orcid.org/0000-0002-5764-6748

Piotr Mazur ${ }^{2}$

https://orcid.org/0000-0002-3488-2940

Lyudmila Matsuk ${ }^{3}$

https://orcid.org/0000-0003-0472-6813

Liudmyla Berezovska ${ }^{4}$

https://orcid.org/0000-0002-3032-7261

Olena Vovk ${ }^{5}$

https://orcid.org/0000-0002-6574-1673

\footnotetext{
${ }^{1}$ Doctor of Pedagogical Sciences, Professor, Director of the Center for Innovative Educational Technologies "PNU EcoSystem", Vasyl Stefanyk Precarpathian National University, Ivano-Frankivsk, Ukraine.

${ }^{2}$ Doctor of Pedagogical Sciences, Professor, The State School of Higher Education in Chelm, Chelm, Poland.

${ }^{3} \mathrm{PhD}$ in Pedagogical Sciences, Associate Professor, Vasyl Stefanyk Precarpathian National University, Ivano-Frankivsk, Ukraine.

${ }^{4}$ Doctor of Pedagogical Sciences, Professor, South Ukrainian National Pedagogical University K. D. Ushinsky, Odessa, Ukraine.

${ }^{5}$ Doctor of Pedagogical Sciences, Associate Professor, Bohdan Khmelnytsky National University at Cherkasy, Cherkasy, Ukraine.
} 
pedagogical process, creative modeling of lessons and educational activities, the creation and implementation of original pedagogical ideas, authoring techniques, etc.

Keywords: Index of Originality, Index of Uniqueness, Future Teachers, Non-Verbal Creativity, Pedagogical Activity.

\section{Introduction}

In today's conditions, raising the requirements for the quality of education, the problem of professional creativity of specialists in various spheres of social life is actualized (Cremin, \& Chappell, 2021; Pavlović, \& Maksić, 2019). First of all, it applies to the pedagogical profession, where the teacher's creativity serves as a means of stimulating cognitive interests of students, increasing their motivation to master new knowledge. At the same time, modern "teachers face the question of how to successfully integrate creativity into teaching practice when teachers have many pressures and little leeway" (Henriksen, \& Mishra, 2013). Often, learning at school means mainly to memorize and reproduce typical methods of action or methods for solving tasks. Such monotony reduces the creative potential of students.

Therefore, urgent is the problem of overcoming pedagogical conservatism, development of student creativity, training of future teachers for implementation of educational innovations in school practice, formation of skills to navigate the market for educational services, etc (Budnyk, Fomin, Novoselska, \& Voitovych, 2020). So, O. Dubaseniuk (2011) sets out a strategy for a creative approach to organizing a pedagogical process in a higher educational institution, which involves: students' awareness of their personal and professional abilities, development of pedagogical abilities to the level of creative; satisfaction of the need for novelty and nonstandard ways of solving professional tasks; setting on creativity and overcoming stereotypical ways and formalism in professional activities; forecasting ways and improving the creative potential of the future teacher. "The development of creative potential is the key to a successful career of students and their professional socialization on the competitive labor market" (Berikkhanova et al., 2015, p. 1146). учителів здатності шукати нестандартні варіанти в організації педагогічного процесу, творчому моделюванні уроків і виховних заходів, створенні та впровадженні оригінальних педагогічних ідей, авторських методик тощо.

Ключові слова: індекс оригінальності, індекс унікальності, майбутні вчителі, невербальна креативність, педагогічна діяльність.

The purpose of the article is to characterize the essence of a teacher's professional creativity; on the basis of comparative experimental research to identify the level of nonverbal creativity of future teachers in the border regions of Ukraine and Poland; define factors that affect the level of pedagogical creativity.

\section{Literature review}

\section{The essence of pedagogical creativity}

The problem of creativity in professional activity has been the subject of the study of philosophers, psychologists, and educators since ancient times. So, in defining different activities, Aristotle argued that creativity (roises) and deeds (ргаxis) are not the same thing. The reseacher refers art to creativity, not to deeds (Aristotle, 1999). Creativity should be aimed at creating works of art and objects of technical production, and actions related to free choice, "practical" (moral and political) life, universal rules of human behavior, general moral and legal norms of citizens of the policy. Consequently, according to the definition of philosophers, the activity involves active interaction of the subject with the object, the final result of which is creation of material or spiritual values, thereby they observe the relationship of the concepts of "activity" and "creativity" (Vasianovych, \& Budnyk, 2017).

Ukrainian researcher of the psychology of creativity V. Romanets argued that it is in this activity that the expression of human individualization, in particular its outlook, takes place. It is the originality and communication that the author considered the characteristics of creative activity, since "the deepening of originality leads to the expansion of communication", hence communication implies "the intensification of originality", therefore, "creativity has a social character and is the interaction of individualities" (Romenets, 2004, p. 121-128) 


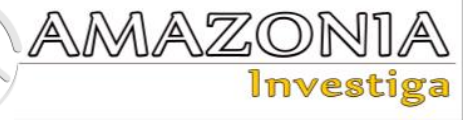

Professional pedagogical activity cannot be stereotyped. It always has a creative character (Hennessey, \& Amabile, 2010; Fullan, \& Langworthy, 2014; Antonova, 2007; Davidovitch, \& Milgram, 2006; Fischer, \& Golden, 2018; Dubaseniuk, 2011; Romenets, 2004; Taddei, 2013; etc.).

American scientists developing ways to integrate creativity into classrooms and explore the role of teachers in enhancing students' creative skills. As "creative people have the ability to maintain a sophisticated knowledge of their field of expertise yet look outside the frames of that field to come up with new ideas" (Henriksen, \& Mishra, 2013). "Creativity comes from synthesis, making new combinations of existing ideas" (Smith, Nerantzi, \& Middleton, 2014).

Pedagogical creativity in professional activity is usually interpreted as a higher level of purposeful human activity in a certain sphere of social life characterized by novelty and social significance of its results. Thus, R. Skulskyi's regarded teacher's pedagogical work as "such a variant of the organization of professional activity, which at the really affordable level provides maximum possible results in the solution of educational tasks in each particular case..." (1992, p. 10). N. Davidovitch, \& R. M. Milgram (2006) emphasize the peculiarities of the teacher's creative thinking and its influence on the efficiency of the pedagogical process in higher education. Mollie S. Aschenbrener, Robert Terry Jr., Robert M. Torres (2010) investigated the influence of creative teaching behaviors on student learning outcomes. "Learning to learn requires that students begin to define their own learning goals and success criteria; monitor their own learning; critically examine their own work; incorporate feedback from peers, teachers, parents or simply other people in general; and use all of this to deepen their awareness of how they function in the learning process" (Fullan, \& Langworthy, 2014, p. 17).

Consequently, creativity as an inalienable characteristic feature of professional activity of the teacher is an active process of selfimprovement, in particular in social and pedagogical activity, the driving force of which is internal and external contradictions. Creative professional activity is always associated with the search for an optimal solution to the problem, adoption of non-standard educational decisions, development and implementation of educational and methodological innovations, development of an individual style of teaching activities, taking into account social queries. "Creativity in education is often an anticipated entailment rather than an actively defined and targeted skill. Even when creativity is deliberately sought, there is still the issue of deciding how to best foster it in teachers and students" (Fischer, \& Golden, 2018, p. 100).

In modern psychological and pedagogical science more and more often agree to the definition of the category of creativity as a complex multi-component psychological phenomenon of a holistic personality. Significant features of creative pedagogical activity, by which it can be distinguished from reproductive (non-creative), R. Skulskyi considered the novelty and social significance of its results. The final results of such activity serve as criteria for identifying its creative nature (1992, p. 13). B. Fischer, \& J. Golden give a definition of creativity that encompass "the widely accepted elements of novelty and value, as well as a strategy to achieve it" (2018, p. 103). Creativity is a combination of those features of the psyche that provide significant transformations in the activity of the individual, which, together with its leading motives, are manifested in the capacity for productive change. For a creative person a bright self-regulation of perception is characteristic, its orientation on the solution of any task, a high level of concentration, etc.

Pedagogical creativity is defined as a set of qualities, the presence and degree of development of which allows the student to creatively approach pedagogical activities (Antonova, 2007, p. 365). Indeed, on the teacher's ability to organize a creative environment in school, depends the attitude of the students to learning, and the creativity, first of all, of 6-7-year-old children undergoing the process of adaptation to school life (Krason, Bonar, Garbula, Jaszczyszyn, Nowak-Łojewska, et al, 2015; Denise de Souza Fleith, 2000). Studies suggest that 'teachers' grade level, subject, experience, and age have no effect on their perception of creative characteristics" (Kettler, Lamb, Willerson, \& Mullet, 2018).

Ch. Smith, Ch. Nerantzi, \& A. Middleton (2014) are perfectly sure, that" truly creative learning spaces are ones in which learners and teachers are mutually engaged in diverse thinking, critiquing each other's viewpoints and working on problems collaboratively". "Working on a creative science project may help developing students' creative abilities, and the interaction between teacher and students during the work on defining a problem and solving the problem, is an 
ideal forum for supporting students' creativity" (Fredagsvik, 2021).

Thus, the teacher's creativity is a natural property of the individual, the highest form of activity, which is embodied in the results of creative professional activity. The creative teacher resolves educational and practical tasks by formulating hypotheses, creating cognitive rules, finding a set of probable and interesting solutions.

\section{Methodology of Research}

\section{General Background of Research}

The research had a comparative character. Future teachers from bordering regions of the two countries participated in the experiment - Old Polish University in Kielce (department in Myślenice), University of Economics and Innovation in Lublin (WSEI), The State School of Higher Education in Chelm (Poland); Lesya Ukrainka Eastern European National University and Vasyl Stefanyk Precarpathian National University (Ukraine).

The purpose of the research is to identify the level of non-verbal creativity in future educators. The experiment involved 304 students studying in Ukraine and 310 students from Poland. The statistical analyses were prepared based on data obtained from the surveys.

\section{Instrument and Procedures}

The mechanism of development of human creativity does not correlate directly with the development of its intelligence, but it is characterized by increasing influence of motivational and personal qualities, in particular, such a specific property of a person as its originality. Thus, the task of our experiment was to diagnose the level of non-verbal creativity of future teachers. As an instrument, we used the technique of E. Torrance (adaptation A. Voronin) (Torrance, 1974; Voronin, 1994).

The survey was conducted during SeptemberNovember 2019 (in Ukraine) and March-May 2019 (in Poland). Students were requested to fill in the proposed drawings with the task. We used 6 unfinished drawings that did not repeat and allowed us to get the most reliable results. Each drawing was given no more than for 2 minutes. The indicators of creativity in the test were originality and uniqueness.

The index of originality was defined as the arithmetic mean of the originals of all images in the proposed atlas. The "originality of the drawing" was estimated on the basis of the amount of data on it and was calculated by the following formula:

$$
O r=1-\frac{x-1}{X_{\max }-1}
$$

where $O r$ is originality of a certain type of drawing; and $x$ is the number of drawings of another type; $X_{m a k s}$ is the maximum number of drawings in a type for a certain sample of respondents.

If the originality of the image (according to Torrens) is equal to 1 , then this drawing is considered unique. The level differentiation of respondents by indices of the index of originality (uniqueness) was conducted on the appropriate scale (Table 1).

Table 1.

The level of differentiation of respondents according to indexes of originality / uniqueness.

\begin{tabular}{lll}
\hline Level & The range of uniqueness indexes & The range of indices of originality \\
\hline High & $3-4$ & $0.83-1$ \\
Sufficient & 2 & $0.58-0.82$ \\
Medium & 1 & $0.33-0.57$ \\
Low & 0 & $0-0.32$ \\
\hline
\end{tabular}

Source: Torrance, 1974; Voronin, 1994; adapted by the authors, 2019.

\section{Results of Research}

The Torrens test was used as a method of identifying the originality of the means of figurative style, the index of uniqueness characterizes the novelty of creation. In analyzing the level of non-verbal creativity, this index is secondary because of the lack of differentiating power.

In the analysis of completed drawings, the main focus was on the use of such details and semantic 


\section{AMAZONDA \\ Investiga}

links by respondents, as well as a comparison of these dwawings with the methods presented in the atlas. This made it possible to calculate

Table 2.

Indices of originality of future teachers in Ukraine and Poland.

\begin{tabular}{lllll}
\hline Levels of development & \multicolumn{2}{l}{ Ukraine (304 students) } & \multicolumn{2}{c}{ Poland (310 students) } \\
\hline & $\mathrm{f}$ & $\%$ & $\mathrm{f}$ & $\%$ \\
High & 10 & 3.3 & 29 & 9.35 \\
Sufficient & 93 & 30.7 & 59 & 19.03 \\
Medium & 144 & 47.3 & 142 & 45.8 \\
Low & 57 & 18.7 & 80 & 25.8 \\
\hline
\end{tabular}

Source: data collected by the authors (2019).

The results of the study indicate that for most future teachers, the average is typical $(47.3 \%$ in Ukraine, $45.8 \%$ in Poland) and low (respectively $18.7 \%$ and $25.8 \%$ ) non-verbal creativity. Such students will be difficult to adapt to the new conditions of their professional environment and to make non-standard decisions in pedagogical practice.

The part of students who are characterized by a high level is very small - 3.3\% among Ukrainians and $9.35 \%$ - Polish students. One indices of originality of Ukrainian and Polish students (Table 2 and Figure 1). third of Ukrainian respondents $(30.7 \%)$ have an index of originality at an adequate level, while in Polish young people, who study to become teachers, this figure is $22.9 \%$. Actually, a high and sufficient level of originality makes possible the use and introduction by teachers of educational innovations, arranging creative authoring teaching methods, etc. However, a high level of creativity of a specialist is possible in case of the possession of "creative abilities, creative skills and creative motivation" (Torrance, 1974).

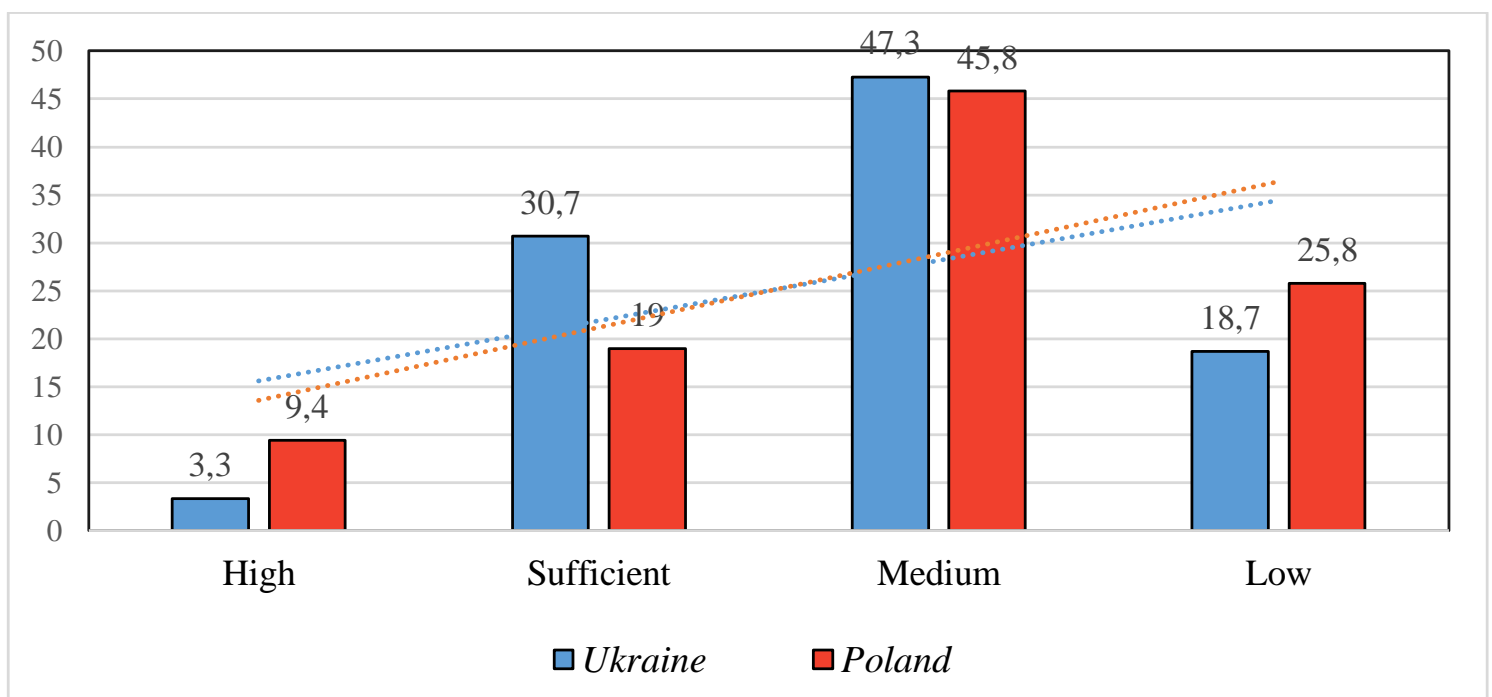

Figure 1. Indices of originality of future teachers in Ukraine and Poland.

Source: authors' calculations based on the conducted survey.

The level of creativity, according to our research, does not depend on a geographical factor, but it also does not exclude the influence of the environment. For example, among Polish students studying at different educational institutions, relatively proportional distributions were found according to the index of originality. So, among 165 students from the Old Polish University in Kielce (Department of Myślenice), the high level of the index of originality was found in $10.3 \%$ of students, sufficient $-14.6 \%$, average $-49.1 \%$ and low $-26.06 \%$. We found similar data in the State School of Higher Education in Chelm (Poland): out of 83 respondents, 9 people showed a high level of originality $(10.8 \%)$, sufficient $-20(24.1 \%)$, average - $34(41 \%)$ and low - 20 (24.1\%). Almost the same data is available at the 
University of Economics and Innovation in Lublin (WSEI): out of 62 students, the high level of the originality index was 17 persons $(27.4 \%)$, average -27 , which is $43.6 \%$ of the total; However, only $4.84 \%$ of future educators had the high level of creativity. In the universities of Western Ukraine, where the study was conducted, there were also no significant differences in the levels of non-verbal creativity of students.

Regarding the distribution of the uniqueness index (Table 3 and Figure 2), a high level was found in $10.9 \%$ of Ukrainian and $16.5 \%$ of Polish respondents.

Table 3.

Distribution of future teachers by levels based on the indices of their uniqueness.

\begin{tabular}{llllc}
\hline Levels of development & \multicolumn{2}{l}{ Ukraine (304 students) } & \multicolumn{2}{l}{ Poland (310 students) } \\
\hline & $f$ & $\%$ & $f$ & $\%$ \\
High & 33 & 10.9 & 51 & 16.45 \\
Sufficient & 89 & 29.3 & 109 & 35.16 \\
Medium & 98 & 32.2 & 110 & 35.48 \\
Low & 84 & 27.6 & 40 & 12.9 \\
\hline
\end{tabular}

Source: data collected by the authors (2019).

Among the respondents from Ukrainian universities, almost a third part of students (29.3\% of the total) showed sufficient, almost the same - average $(32.2 \%)$ and low $(27.6 \%)$ levels. Among the future teachers from Poland, this indicator is not significantly different: in fact the same number of people proved sufficient $(35.16 \%)$ and average $(35.48 \%)$ levels of nonverbal creativity according to the uniqueness index.

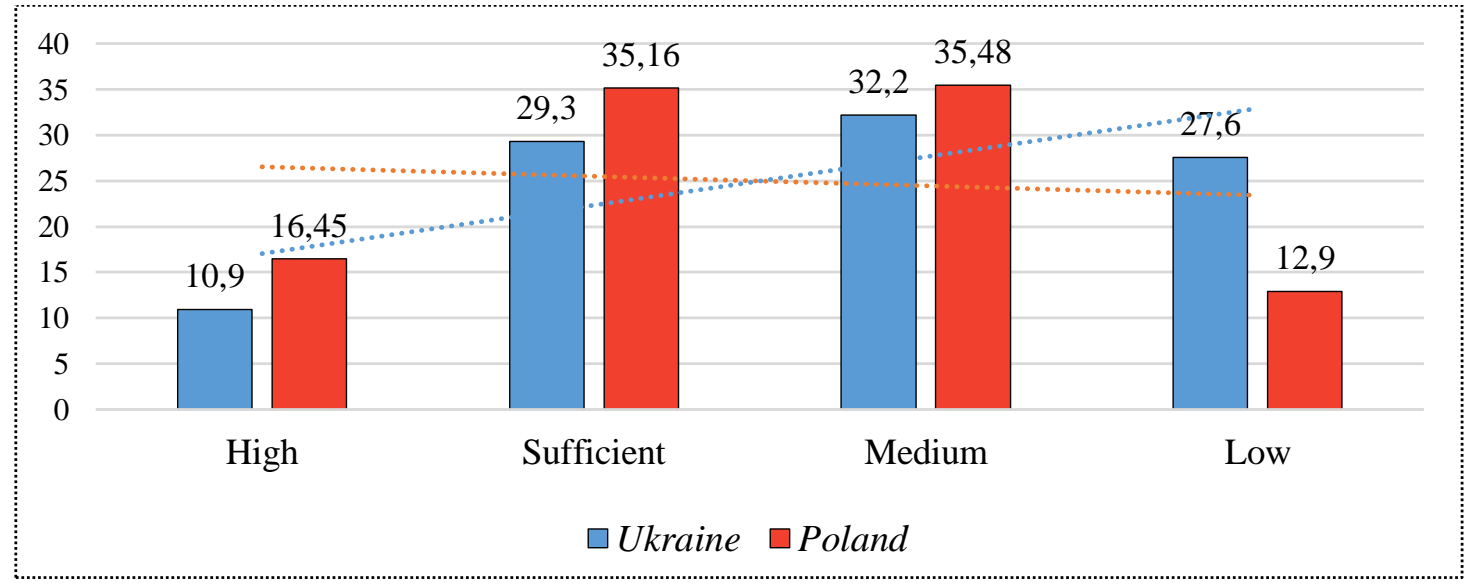

Figure 2. Uniqueness index of students in Ukraine and Poland.

Source: authors' calculations based on the conducted survey.

However, among Ukrainian students, more than twice is higher a low level of creativity -84 respondents, representing $27.6 \%$ (in Poland this figure is only $12.9 \%$ (40 people). The low level of the uniqueness index testifies young people's unwillingness or incapacity to create unique works (drawings). In professional activities this may be reflected in standardized approaches to solving pedagogical situations, inability to solve non-typical professionally-oriented tasks, lack of initiatives and desire to identify their individuality. It is obvious that in this case, the development of creativity in Polish higher education institutions is more influenced by socio-psychological conditions: greater openness in communication, spontaneity, autonomy and confidence of the student, environment of trust, openness, freedom and novelty (Budnyk \& Mazur, 2017).

At the same time, in the post-Soviet Space there still exsist a certain tenderness, conservative perception of pedagogical reality.

\section{Discussions}

The result of creative development of a person is creativity. In psychological and pedagogical 


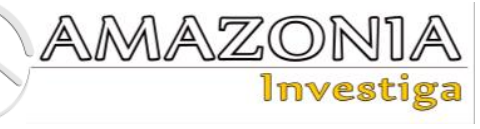

science, creativity is understood as a complex of intellectual and personal characteristics of the individual, contributing to the independent generation of original ideas and their nontraditional solution.

In the framework of synergetic (non-classical) methodology, we define the principle of nonlinearity in the preparation of a teacher, which implies "the need for an innovative, nonclassical perception of the world on the basis of taking into account modern studies of social and humanitarian sciences", "openness, variability, flexibility, mobility of formation of knowledge, skills, social and pedagogical content through the synthesis of basic and special courses, development of subjectivity, stimulating creativity" (Budnyk, 2014, p. 209-210). This thinking of a qualified specialist is aimed at solving complex systems taking into account the latest methodological grounds, methods and means.

According to the results of the diagnosis of nonverbal creativity, we can conclude that prevailing number of future teachers in Ukraine and Poland is unable to produce sufficient original ideas in a minimal verbalization. They use simple, traditional ways to solve practical problems, producing template ideas. According to A. Maslow, who considered creativity "a universal characteristic of all self-actualized people" (Maslow, 2006, p. 222), these students will not be able to fully self-realize in a professional environment. Many of them may be unmotivated, inclined to make decisions prematurely, without taking into account all available information. Therefore, in the context of a higher educational institution, it is important to direct the content of education to the development of future teachers' ability to seek non-traditional options in organizing the pedagogical process, creative modeling of lessons and educational activities, creation of original pedagogical ideas, etc. "The approach to the revelation of creative abilities of future teachers involves the rejection of established patterns and stereotypical behavior techniques, and requires the application of innovation, creativity and ingenuity of a teacher" (Berikkhanova et al., 2015, p. 1146).

Thus, the development of the professional creativity of the future teacher involves mastering methods, techniques, methods of organizing creative activity. Undoubtedly, it is about mastering them with the appropriate pedagogical tools of creativity and their use in practice, strengthening the relationship between theoretical and practical knowledge "in the processes of developing special professional competences ... of future teachers", in particular creative thinking in pedagogical activities (Rovnaňová, \& Nemcová, 2017, p. 177). After students are prepared for solving a system of professionally oriented tasks at different levels in the context of triad activity: creativity, skill, activity.

B. Jeffrey, \& A. Craft (2004) show the relationship between teaching creatively and teaching for creativity:

1) teachers teach creatively and teach for creativity according to the circumstances they consider appropriate and sometimes they do both at the same time;

2) teaching for creativity may well arise spontaneously from teaching situations in which it was not specifically intended;

3) teaching for creativity is more likely to emerge from contexts in which teachers are teaching creatively. Learners model themselves on their teacher's approach, find themselves in situations where they are able to take ownership and control and are more likely to be innovative, even if the teacher was not overtly planning to teach for creativity.

The development of professional creativity of future teachers in higher education involves the use of pedagogical innovations, active learning methods in particular, "sharing ideas across discipline", "creating an environment of open collaboration", and "providing for interdisciplinary and capstone courses as well as cross-class projects", etc. "Creating an environment of trust is a critical component of promoting innovation and creativity" (Taddei, 2013).

\section{Conclusions}

On the level of creativity (in particular, nonverbal) students are influenced by factors such as: motivation, value orientations, the presence of a suitable environment, a sense of freedom in activity, adequate and steady self-esteem, etc. As a result of the study we draw the conclusion: creativity should be considered in the structure of the integral personality of the future teacher.

Professional creativity is manifested in the students' clear awareness of the possibilities of modeling the creative environment in school, feeling of professional freedom, overcoming stereotypical notions about the pedagogical profession, creative solution of professionally 
oriented tasks, the non-standard approach to modeling the educational process, the creative use of verbal and nonverbal means of pedagogical interaction with Students, striving for creative self-development and selfdevelopment.

\section{Bibliographic references}

Antonova, O. Ye. (2007). Theoretical and methodical principles of teaching pedagogically gifted students, monograph. Zhytomyr, Ukraine: Vyd-vo ZhDU.

Aristotle (1999). Nicomachean Ethics, translation by W. D. Ross. Kitchener: Batoche Books. https://socialsciences.mcmaster.ca/econ/ugc $\mathrm{m} / 3113$ /aristotle/Ethics.pdf

Aschenbrener, M., Terry, R., \& Torres, R. (2010). Creative and Effective Teaching Behaviors of University Instructors as Perceived by Students. Journal of Agricultural Education, 51 (3), 64-75. Doi: 10. 5032/jae.2010.0306464.

Berikkhanova, A. E., Zhussupova, Zh. A., \& Berikkhanova, G. Ye. (2015). Developing creative potential of future teachers: research and results. Procedia - Social and Behavioral Sciences, 171, 1142-1146. doi: 10.1016/j.sbspro.2015.01.222.

Budnyk, O. (2014). Professional training of primary school teachers to social and educational activities: Theory and Practice, monograph. Dnipropetrovsk, Ukraine: "Seredniak T.K.". http://194.44.152.155/elib/local/2289.pdf (in Ukrainian).

Budnyk, O., \& Mazur, P. (2017). The Hierarchy of Values Among Young People from Schools in the Mountainous Regions (Comparative study on the example of Poland and Ukraine). The New Educational Review, 47 (1), 53-65. doi: 10.15804/tner.2017.47.1.04

Budnyk, O., Fomin, K., Novoselska, N., \& Voitovych, A. (2020). Preparing Teachers to Organize Dialogic Learning of Students: Communicative Aspect. Revista Inclusiones, 7(4), 117-129.

Cremin, T, \& Chappell, K. (2021). Creative pedagogies: a systematic review. Research Papers in Education, 36(3), 299-331. https://doi.org/10.1080/02671522.2019.1677 757

Davidovitch, N., \& Milgram, R. M. (2006). Creative thinking as a predictor of teacher effectiveness in higher education. Creativity Research Journal, 18 (3), 385-390. de Souza Fleith, D (2000). Teacher and student perceptions of creativity in the classroom environment. Roeper Review, 22 (3), 148-153. https://doi.org/10.1080/02783190009554022

Dubaseniuk, O. A. (2011). Creative approach to vocational and pedagogical training of future teachers. Creative Pedagogy, 4, 23-28. http://eprints.zu.edu.ua/12838/1/23.pdf (in Ukrainian).

Fischer, B., \& Golden, J. (2018). Modelling and Fostering Creativity: Two Post-Secondary EAL Teachers' Journey. Canadian Journal of Education, 41 (1), 98-123.

Fredagsvik, M. S. (2021). The challenge of supporting creativity in problem-solving projects in science: a study of teachers' conversational practices with students. Research in Science \& Technological Education, 1-17. https://doi.org/10.1080/02635143.2021.1898 359

Fullan, M., \& Langworthy, M. (2014). A rich seam: How new pedagogies find deep learning. Pearson. https://www.michaelfullan.ca/wpcontent/uploads/2014/01/3897.Rich_Seam_ web.pdf

Hennessey, B. A., \& Amabile, T. M. (2010). Creativity. Annual Review of Psychology, 61 (1), 569-598. Doi: 10.1146/annurev.psych.093008.100416

Henriksen, D., \& Mishra, P. (2013). Learning from Creative Teachers. Educational Leadership, $70 \quad$ (5), http://www.ascd.org/publications/educationa 1-leadership/feb13/vol70/num05/Learningfrom-Creative-Teachers.aspx

Jeffrey, B., \& Craft, A. (2004). Teaching creatively and teaching for creativity: distinctions and relationships. Educational Studies, $30(1), \quad 77-87$. https://doi.org/10.1080/03055690320001597 50

Kettler, T., Lamb, K. N., Willerson, A., \& Mullet, D. R. (2018). Teachers' Perceptions of Creativity in the Classroom. Creativity Research Journal, 30(2), 164-171. https://doi.org/10.1080/10400419.2018.1446 503

Krasoń, K., Bonar, J., Garbula, J., Jaszczyszyn, E., Nowak-Łojewska, A., Łączyk, M., Kopaczyńska, I., Olczak, A., Różańska, A., \& Tyl, A. (2015). Dimorphic Outlook on Children's Creative Attitudes on the Verge of Education Application of Creative and Re-constructive Attitudes Rating Scale (SPTO). The New Educational 


\section{AMAZONDA \\ Investiga}

Review, $42 \quad$ (4), 285-297. Doi: 10.15804/tner.2015.42.4.24

Maslow, A. (2006). Motivation and Personality, 3rd ed., Moscow-St. Petersburg, Russia: Piter.

Pavlović, Je., \& Maksić, S. (2019). Implicit Theories of Creativity in Higher Education: A Constructivist Study. Journal of Constructivist Psychology, 32(3), 254-273. https://doi.org/10.1080/10720537.2018.1477 639

Romenets, V. A. (2004). Psychology of creativity: a manual, 3rd ed. Kyiv, Ukraine: Lybid.

https://chtyvo.org.ua/authors/Romenets_Vol odymyr/Psykholohiia_tvorchosti/_ (in Ukrainian).

Rovnaňová, L., \& Nemcová, L. (2017). Integration of Theoretical and Practical Undergraduate Training in the Processes of Developing Student Teachers' Professional Competences. The New Educational Review, 47 (1), 176-186. Doi: 10.15804/tner.2017.47.1.14

Skulskyi, R. P. (1992). Preparation of future teachers for pedagogical creativity, monograph. Kyiv, Ukraine: Vyshcha shkola.
Smith, Ch., Nerantzi, Ch., \& Middleton, A. (2014). Promoting Creativity in Learning and Teaching. UK: University Campus Suffolk, Manchester Metropolitan University, Sheffield Hallam University. http://www.iced2014.se/proceedings/1120_S mith.pdf

Taddei, L. (2013). Encouraging Creativity and Innovation in Yourself and Your Students. Faculty focus. https://www.facultyfocus.com/articles/facult $\mathrm{y}$-development/encouraging-creativity-andinnovation-in-yourself-and-your-students/

Torrance, E. P. (1974). Torrance Tests of Creative Thinking. Lexington, Mass.: Personnel Press. https://www.worldcat.org/title/torrancetests-of-creativethinking/oclc/504033487?referer=di\&ht=edi tion

Vasianovych, H., \& Budnyk, O. (2017). The Category of freedom in the written heritage of John Amos Comenius and Hryhoriy Skovoroda. Advanced Education, 7, 85-89. doi: 10.20535/2410-8286.93517.

Voronin, A. N. (1994). Methods of psychological diagnostics. Moscow: DOCKniga. https://gigabaza.ru/doc/3470-pall.html 